\title{
DISTURBANCES IN VESSEL TRAFFIC STREAM DUE TO FAIRWAY REGULATIONS
}

\section{ZABURZENIA STRUMIENIA RUCHU STATKÓW PRZEPISAMI TOROWYMI}

\author{
Lech Kasyk \\ Maritime University, Department of Mathematics \\ Akademia Morska, Zakład Matematyki \\ 70-500 Szczecin ul. Wały Chrobrego 1/2 \\ e-mail: lkasyk@am.szczecin.pl
}

\begin{abstract}
All regulations disturb the randomness of the vessel traffic stream. In the present paper the effect of the following regulations on the vessel traffic stream has been analysed: the order to maintain minimum distance between successive vessels, speed limit, overtaking ban, passing ban. These regulations disturb the Poissonian nature of the stream of reports. Using the method of random variables convolution the density function of probability was determined of the disturbed vessels' stream of reporting for particular factors controlling traffic on the fairway.
\end{abstract}

Keywords: vessel traffic, Poisson process, convolution of distribution, port regulations

Streszczenie: Wszelkie regulacje zaburzają losować strumienia ruchu statków. W niniejszym referacie przeanalizowano wpływ następujących regulacji na strumień ruchu statków: ograniczenie prędkości, zakaz wyprzedzania, zakaz wymijania. Przepisy te zaburzają Poissonowski charakter strumienia zgłoszeń. Wykorzystując metodę splotów zmiennych losowych wyznaczono funkcję gęstości prawdopodobieństwa zaburzonego strumienia zgłoszeń statków dla poszczególnych czynników, regulujących ruch na torze wodnym.

Slowa kluczowe: ruch statków, proces Poissona, splot rozkładów, przepisy portowe 


\section{DISTURBANCES IN VESSEL TRAFFIC STREAM DUE TO FAIRWAY REGULATIONS}

\section{Introduction}

Vessel traffic on a fairway is only partially random, and partially controlled. All regulations disturb the randomness of the vessel traffic stream. In the present paper the effect of the following regulations on the vessel traffic stream has been analysed: the order to maintain minimum distance between successive vessels, speed limit, overtaking ban, passing ban. These regulations disturb the Poissonian nature of the stream of reports. Using the method of random variables convolution the density function of probability was determined of the disturbed vessels' stream of reporting for particular factors controlling traffic on the fairway.

\section{Passing ban}

On narrow fairways or those for large vessels restrictions are frequently introduced in the form of a passing ban on certain fairway sections [12]. Therefore, a vessel approaching a special fairway section (section $\mathrm{P}_{1} \mathrm{P}_{2}$ in Fig.1), where the ban is in force, stops before point $\mathrm{P}_{1}$. She waits for the vessel in section $\mathrm{P}_{1} \mathrm{P}_{2}$ to leave it and next continue sailing.

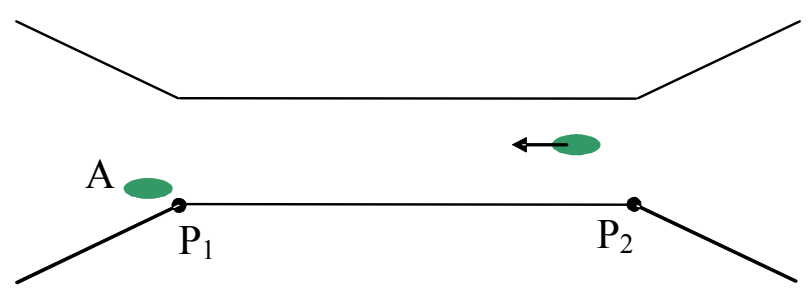

Fig. 1. Passing ban on special section $\mathrm{P}_{1} \mathrm{P}_{2}$

Considering the movement of two successive fairway vessels (A and B) stopping at the entrance to the fairway section with a passing ban, the time between them can be determined, when they resume their sailing. If vessel A reports at point $\mathrm{P}_{1}$ at time $t_{0}$, then, waiting for entering section $\mathrm{P}_{1} \mathrm{P}_{2}$ for 
time $Y_{\mathrm{A}}$, she starts movement on the special section at time $t_{0}+Y_{\mathrm{A}}$. The next vessel reports at point $\mathrm{P}_{1}$ at time $t_{0}+X_{\mathrm{B}}$. If the waiting time for entering is equal to $Y_{\mathrm{B}}$, she will enter section $\mathrm{P}_{1} \mathrm{P}_{2}$ at time $t_{0}+X_{\mathrm{B}}+Y_{\mathrm{B}}$. Hence, the time between vessels $A$ and $B$ entering section $\mathrm{P}_{1} \mathrm{P}_{2}$ is equal to:

$$
T=X_{B}+\left(Y_{B}-Y_{A}\right)
$$

Particular times occurring in this expression are random variables. Variable $X$ is the most frequently modelled exponential distribution $[1,3,4,9,10]$, whereas variables $Y_{\mathrm{B}}$ and $Y_{\mathrm{A}}$ are realisations of the same variable $Y$, which most frequently has an empirical distribution characteristic for a given kind of water area [6]. Applying convolution operation [5, 7, 8, 11] of the density function of particular random variables, it is possible to determine the time density function between vessels $\mathrm{A}$ and $\mathrm{B}$ entering section $\mathrm{P}_{1} \mathrm{P}_{2}$. This function can be symbolically presented in the form:

$$
f(x)=\operatorname{conv}\left(f_{X}(x), f_{Y A-Y B}(x)\right)
$$

where

$\operatorname{conv}(f, g)$ - convolution of functions $f$ and $g$;

$f_{X}$ - density function of variable $X$;

$f_{Y B-Y A}-$ density function of difference $Y_{\mathrm{A}}-Y_{\mathrm{B}}$;

In some cases, waiting time can be presented as a random variable with uniform distribution [7]. Using formula (2) the density function of random variable $Y_{\mathrm{B}}-Y_{\mathrm{A}}$ was determined first:

$$
f_{Y B-Y A}(x)= \begin{cases}\frac{x+b-a}{(b-a)^{2}} & \text { for } a-b \leq x<0 \\ \frac{-x+b-a}{(b-a)^{2}} & \text { for } 0 \leq x<b-a\end{cases}
$$

where

$a, b$ - parameters of uniform distribution.

Next, applying the operation of convolution of exponential density function $f_{X}$ with function $f_{Y B-Y A}(x)$ the density function was obtained of time between vessels $\mathrm{A}$ and $\mathrm{B}$ entering section $\mathrm{P}_{1} \mathrm{P}_{2}$ : 


$$
f_{T}(u)=\left\{\begin{array}{l}
\frac{1-(u-b+a) \cdot \lambda+(2 a \lambda-2 b \lambda-1) \cdot e^{(a-u-b) \lambda}}{(b-a)^{2} \cdot \lambda} \text { for } a-b \leq u<0 \\
\frac{(u-b+a) \cdot \lambda-1+2 e^{-u \lambda}+(2 a \lambda-2 b \lambda-1) \cdot e^{(a-u-b) \lambda}}{(b-a)^{2} \cdot \lambda} \text { for } 0 \leq u<b-a \\
\frac{2 e^{-u \lambda}+(2 b \lambda-2 a \lambda-1) \cdot e^{(b-u-a) \lambda}+(2 a \lambda-2 b \lambda-1) \cdot e^{(a-u-b) \lambda}}{(b-a)^{2} \cdot \lambda} \text { for } b-a \leq u<\infty
\end{array}\right.
$$

where

$\lambda$ - parameter of exponential distribution.

\section{Overtaking ban}

Another restriction in narrow fairways is the overtaking ban on certain sections of the fairway [12]. Therefore, the vessel getting close to another vessel proceeding ahead of her must adapt her speed to the speed of the vessel she must not overtake. Considering the particular phases of the movement: slowing down, following a slower vessel and accelerating, a general form of density function was determined of the waiting time for the reporting of the successive vessel leaving the area with the overtaking ban in force:

$$
T=X+\left(Y_{B}-Y_{A}\right)+\left(W_{B}-W_{A}\right)+\left(Z_{B}-Z_{A}\right)
$$

where $X$ denotes the time between reporting of fairway vessels in undisturbed vessel traffic, $Y_{\mathrm{B}}$ and $Y_{\mathrm{A}}$ are realisations (for units $\mathrm{A}$ and $\mathrm{B}$ ) of variable $Y$, which denotes the time necessary for adapting speed to speed of slower unit; $W_{\mathrm{B}}$ and $W_{\mathrm{A}}$ are realisations of variable $W$, which denotes the time necessary for covering the section with the overtaking ban; $Z_{\mathrm{B}}$ and $Z_{\mathrm{A}}$ are realisations of variable $Z$, which denotes the time necessary for the overtaking of slower unit after covering the special section. The density function of variable $T$ is a convolution of four density functions $[5,7]$ :

$$
f_{T}(x)=\operatorname{conv}\left(f_{X}(x), f_{Y B-Y A}(x), f_{W B-W A}(x), f_{Z B-Z A}(x)\right)
$$


Three of the density functions appearing in the above density function formula are densities of random variable differences also determined by the convolution method.

\section{Speed limit on a section of the fairway}

A fairway vessel getting close to a fairway section with speed limit in force, must adapt her speed to the current regulations. Considering the successive movement phases of two successive vessels on the fairway (A and B) while passing a section with speed limit [8], the density function was determined of the time $(T)$ between successive vessels leaving the special fairway section. Variable $T$ is the sum of four random variables:

$T=X+\left(Y_{B}-Y_{A}\right)+\left(W_{B}-W_{A}\right)+\left(Z_{B}-Z_{A}\right)$

where $X$ denotes the time between reporting of fairway vessels in undisturbed vessel traffic, $Y_{\mathrm{B}}$ and $Y_{\mathrm{A}}$ are realisations (for units $\mathrm{A}$ and $\mathrm{B}$ ) of variable $Y$, which denotes the time necessary for adapting speed to the current regulations; $W_{\mathrm{B}}$ and $W_{\mathrm{A}}$ are realisations of variable $W$, which denotes the time necessary for covering the section with the speed limit; $Z_{\mathrm{B}}$ and $Z_{\mathrm{A}}$ are realisations of variable $Z$, which denotes the time necessary for reaching full speed after covering the special section. The density function of variable $T$ is a convolution of four density functions:

$$
f_{T}(x)=\operatorname{conv}\left(f_{X}(x), f_{Y B-Y A}(x), f_{W B-W A}(x), f_{Z B-Z A}(x)\right)
$$

Three of the density functions appearing in the above density function formula are densities of random variable differences also determined by the convolution method. In the case when variables $Y, W$ and $Z$ are modelled by normal distribution [7,8], and variable $X$ by exponential distribution, the density function of variable $T$ assumes the following form:

$$
\begin{array}{r}
f_{T}(x)=\frac{\lambda}{2} \exp \left(\lambda^{2}\left(\sigma_{Y}^{2}+\sigma_{W}^{2}+\sigma_{Z}^{2}\right)-\lambda x\right) . \\
\cdot\left(1+\operatorname{erf}\left(\frac{x-2 \lambda\left(\sigma_{Y}^{2}+\sigma_{W}^{2}+\sigma_{Z}^{2}\right)}{2 \sqrt{\sigma_{Y}^{2}+\sigma_{W}^{2}+\sigma_{Z}^{2}}}\right)\right)
\end{array}
$$


where

$\sigma_{Y}-$ standard deviation of variable $Y$;

$\sigma_{W}$-standard deviation of variable $W$.

$\sigma_{Z}-$ standard deviation of variable $Z$.

$\lambda$ - parameter of exponential distribution;

$\operatorname{erf}(x)$ - error function used in Mathematica programme [2].

\section{Recapitulation}

Restrictions in vessel traffic on a fairway caused by fairway regulations make the vessel traffic stream cease to be a Poisson stream. Singling out particular vessel movement phases for the restrictions considered and the application of convolution distribution method permitted the determination of a general density function form of the waiting time for the successive vessel's reporting in a disturbed vessel traffic stream. To determine particular density functions for a definite water area research is indispensable, aimed at the determination of probability distributions best describing all variables appearing in particular vessel traffic phases.

\section{Literature}

1. Ciletti M., Traffic Models for use in Vessel Traffic Systems, The Journal of Navigation 31/1978

2. Drwal G., Grzymkowski R., Kapusta A., Słota D., Mathematica 4, Wydawnictwo Pracowni Komputerowej Jacka Skalmierskiego, Gliwice, 2000.

3. Fujii Y., Development of Marine Traffic Engineering in Japan, The Journal of Navigation 30/1977

4. Gajek L., Kałuszka M., Wnioskowanie statystyczne, WNT Warszawa 1996.

5. Gucma L., Modele probabilistyczne do oceny bezpieczeństwa statków na akwenach ograniczonych oparte na splotach rozktadów jednostajnego i normalnego, Zeszyty Naukowe AM Szczecin 11(83), Szczecin 2004. 
6. Kasyk L., Empirical distribution of the number of ship reports on the fairway Szczecin - Świnoujście, XIV-th International Scientific and Technical Conference The role of navigation in support of human activity on the sea", Gdynia 2004.

7. Kasyk L., Intensity of vessel traffic after passing a lock, III International conference Inladshiping 2007, Szczecin 2007.

8. Kasyk L., Wpływ ograniczenia prędkości na proces zgłoszenia jednostek torowych, Konferencja LogiTrans, Szczyrk 2008.

9. Kose E., Basar E., Demrici E., Erkebay S., Simulation of marine traffic in Istanbul Strait, Simulation Modelling Practice and Theory 11/2003.

10. Montgomery D. C., Runger G. C., Applied statistics and probability for engineers, John Wiley \& Sons, Inc., New York, 1994.

11. Nowak R., Statystyka dla fizyków, Wydawnictwo Naukowe PWN, Warszawa, 2002.

12. Przepisy portowe, Urząd Morski w Szczecinie, Szczecin 2007 


\section{ZABURZENIA STRUMIENIA RUCHU STATKÓW PRZEPISAMI TOROWYMI}

\section{Wstęp}

Ruch statków na torze wodnym jest tylko częściowo losowy, a częściowo jest regulowany. Wszelkie regulacje zaburzają losować strumienia ruchu statków. W niniejszym referacie przeanalizowano wpływ następujących regulacji na strumień ruchu statków: nakaz zachowania minimalnej odległości między kolejnymi statkami, ograniczenie prędkości, zakaz wyprzedzania, zakaz wymijania. Przepisy te zaburzaja Poissonowski charakter strumienia zgłoszeń. Wykorzystując metodę splotów zmiennych losowych wyznaczono funkcję gęstości prawdopodobieństwa zaburzonego strumienia zgłoszeń statków dla poszczególnych czynników, regulujących ruch na torze wodnym.

\section{Zakaz wymijania}

$\mathrm{Na}$ wąskich torach wodnych lub dla dużych jednostek, często wprowadza się ograniczenia polegające na zakazie wymijania się na pewnych odcinkach toru wodnego [12]. W związku $\mathrm{z}$ tym, jednostka zbliżająca się do specjalnego odcinka toru (na rys. 1 odcinek $\mathrm{P}_{1} \mathrm{P}_{2}$ ), na którym obowiązuje zakaz, zatrzymuje się przed punktem $\mathrm{P}_{1}$. Czeka, aż jednostka znajdująca się na odcinku $\mathrm{P}_{1} \mathrm{P}_{2}$ opuści go i następnie kontynuuje żeglugę.

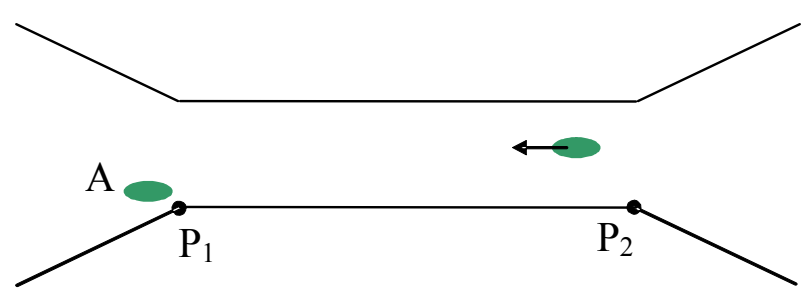

Rys. 1. Zakaz wymijania na odcinku spejalnym $\mathrm{P}_{1} \mathrm{P}_{2}$

Rozpatrując ruch dwóch kolejnych jednostek torowych (A i B) zatrzymujących się na wejściu do odcinka toru wodnego $\mathrm{z}$ zakazem 
wymijania, można określić czas pomiędzy nimi, gdy rozpoczynają na nowo swoją żeglugę. Jeżeli jednostka A zgłasza się do punktu $\mathrm{P}_{1}$ o godzinie $\mathrm{t}_{0}$, to czekając na wejście na odcinek $\mathrm{P}_{1} \mathrm{P}_{2}$ przez czas $Y_{\mathrm{A}}$, rozpoczyna ruch na odcinku specjalnym o godzinie $t_{0}+Y_{\mathrm{A}}$. Następna jednostka zgłasza się do punktu $\mathrm{P}_{1}$ o godzinie $t_{0}+X_{\mathrm{B}}$. Jeżeli czas oczekiwania na wejście wynosi $Y_{\mathrm{B}}$, to wpłynie ona na odcinek $\mathrm{P}_{1} \mathrm{P}_{2}$ o godzinie $t_{0}+X_{\mathrm{B}}+Y_{\mathrm{B}}$. Stąd czas pomiędzy wejściem statków A i B na odcinek $\mathrm{P}_{1} \mathrm{P}_{2}$ wynosi:

$$
T=X_{B}+\left(Y_{B}-Y_{A}\right)
$$

Poszczególne czasy występujące w tym wyrażeniu są zmiennymi losowymi. Zmienna $X$ jest najczęściej modelowana rozkładem wykładniczym [1, 3, 4, 9, 10], natomiast zmienne $Y_{\mathrm{B}}$ i $Y_{\mathrm{A}}$ są realizacjami tej samej zmiennej $Y$, która ma najczęściej rozkład empiryczny charakterystyczny dla danego rodzaju akwenu [6]. Stosując operację splotów [5, 7, 8, 11] funkcji gęstości poszczególnych zmiennych losowych, można wyznaczyć funkcję gęstości czasu pomiędzy wejściem statków A i B na odcinek $\mathrm{P}_{1} \mathrm{P}_{2}$. Funkcję tę można symbolicznie przedstawić $\mathrm{w}$ postaci:

$$
f(x)=\operatorname{conv}\left(f_{X}(x), f_{Y B-Y A}(x)\right)
$$

gdzie

$\operatorname{conv}(f, g)-\operatorname{splot}$ funkcji $f$ i $g$;

$f_{X}$ - funkcja gęstości zmiennej $X$;

$f_{Y B-Y A}$ - funkcja gęstości różnicy zmiennych losowych $\left(Y_{B}-Y_{A}\right)$;

W niektórych wypadkach czas oczekiwania można przedstawić jako zmienną losową o rozkładzie jednostajnym [7]. Wykorzystując wzór (2) wyznaczono najpierw funkcję gęstości zmiennej $Y_{\mathrm{B}}-Y_{\mathrm{A}}$ :

$$
f_{Y B-Y A}(x)= \begin{cases}\frac{x+b-a}{(b-a)^{2}} & \text { for } a-b \leq x<0 \\ \frac{-x+b-a}{(b-a)^{2}} & \text { for } 0 \leq x<b-a\end{cases}
$$

gdzie

$a, b$ - parametry rozkłady jednostajnego. 
Następnie stosując operację splotu wykładniczej funkcji gęstości $f_{X} \mathrm{z}$ funkcją $f_{Y B-Y A}(x)$ otrzymano funkcję gęstości czasu pomiędzy wejściem statków A i B na odcinek $\mathrm{P}_{1} \mathrm{P}_{2}$ :

$$
f_{T}(u)=\left\{\begin{array}{l}
\frac{1-(u-b+a) \cdot \lambda+(2 a \lambda-2 b \lambda-1) \cdot e^{(a-u-b) \lambda}}{(b-a)^{2} \cdot \lambda} \text { for } a-b \leq u<0 \\
\frac{(u-b+a) \cdot \lambda-1+2 e^{-u \lambda}+(2 a \lambda-2 b \lambda-1) \cdot e^{(a-u-b) \lambda}}{(b-a)^{2} \cdot \lambda} \text { for } 0 \leq u<b-a \\
\frac{2 e^{-u \lambda}+(2 b \lambda-2 a \lambda-1) \cdot e^{(b-u-a) \lambda}+(2 a \lambda-2 b \lambda-1) \cdot e^{(a-u-b) \lambda}}{(b-a)^{2} \cdot \lambda} \text { for } b-a \leq u<\infty
\end{array}\right.
$$

gdzie

$\lambda$ - parametr rozkładu wykładniczego.

\section{Zakaz wyprzedzania}

Innym ograniczeniem na wąskich torach wodnych jest zakaz wyprzedzania na pewnych odcinkach toru wodnego [12]. W związku z tym, jednostka zbliżająca się do innej jednostki, płynącej przed nią, musi dostosować swoją prędkość do prędkości statku, którego nie może wyprzedzić. Rozpatrując poszczególne fazy ruchu: zwalnianie, płynięcie za jednostką wolniejszą (w przepisowej odległości za nią) i przyspieszanie wyznaczono ogólną postać funkcji gęstości czasu oczekiwania na zgłoszenie kolejnej jednostki wychodzącej z obszaru, w którym obowiązuje zakaz wyprzedzania:

$T=X+\left(Y_{B}-Y_{A}\right)+\left(W_{B}-W_{A}\right)+\left(Z_{B}-Z_{A}\right)$

gdzie $X$ oznacza czas pomiędzy zgłoszeniami jednostek torowych w niezaburzonym ruchu statków, $Y_{\mathrm{B}}$ i $Y_{A}$ są realizacjami zmiennej $Y$, która oznacza czas potrzebny na dostosowanie prędkości do prędkości jednostki wolniejszej; $W_{\mathrm{B}}$ i $W_{\mathrm{A}}$ są realizacjami zmiennej $W$, która oznacza czas potrzebny na pokonanie odcinka $\mathrm{z}$ zakazem wyprzedzania; $Z_{\mathrm{B}}$ i $Z_{\mathrm{A}}$ sa realizacjami zmiennej $Z$, która oznacza czas potrzebny na wyprzedzenie wolniejszej jednostki, po przepłynięciu odcinka z zakazem wyprzedzania. Funkcja gęstości zmiennej $T$ jest splotem czterech funkcji gęstości $[5,7]$ :

$$
f_{T}(x)=\operatorname{conv}\left(f_{X}(x), f_{Y B-Y A}(x), f_{W B-W A}(x), f_{Z B-Z A}(x)\right)
$$


Trzy z występujących w powyższym wzorze funkcji gęstości to gęstości różnic zmiennych losowych wyznaczone również metodą splotów.

\section{Ograniczenie prędkości na pewnym odcinku toru wodnego}

Jednostka torowa zbliżająca się do odcinka toru wodnego, na którym obowiązuje ograniczenie prędkości, musi dostosować swą prędkość do obowiązujących przepisów. Rozpatrując kolejne fazy ruchu dwóch kolejnych statków na drodze wodnej (A i B), podczas przechodzenia przez odcinek z ograniczeniem prędkości [8], wyznaczono funkcję gęstości czasu (T) pomiędzy kolejnymi statkami opuszczającymi specjalny odcinek toru. Zmienna $T$ to suma czterech zmiennych losowych:

$$
T=X+\left(Y_{B}-Y_{A}\right)+\left(W_{B}-W_{A}\right)+\left(Z_{B}-Z_{A}\right)
$$

gdzie $X$ oznacza czas pomiędzy zgłoszeniami jednostek torowych w niezaburzonym ruchu statków, $Y_{\mathrm{B}}$ i $Y_{\mathrm{A}}$ są realizacjami zmiennej $Y$, która oznacza czas potrzebny na dostosowanie prędkości do obowiązujących przepisów; $W_{\mathrm{B}}$ i $W_{\mathrm{A}}$ są realizacjami zmiennej $W$, która oznacza czas potrzebny na pokonanie odcinka $\mathrm{z}$ ograniczeniem prędkości; $Z_{\mathrm{B}}$ i $Z_{\mathrm{A}}$ są realizacjami zmiennej $Z$, która oznacza czas potrzebny na to, by po przepłynięciu odcinka specjalnego, jednostka osiagnęła pełną prędkość. Funkcja gęstości zmiennej $T$ jest splotem czterech funkcji gęstości:

$$
f_{T}(x)=\operatorname{conv}\left(f_{X}(x), f_{Y B-Y A}(x), f_{W B-W A}(x), f_{Z B-Z A}(x)\right)
$$

Trzy $\mathrm{z}$ występujących $\mathrm{w}$ powyższym wzorze funkcji gęstości to gęstości różnic zmiennych losowych wyznaczone również metodą splotów. W przypadku, gdy zmienne $Y, W$ i $Z$ są modelowane rozkładem normalnym [7, 8], a zmienna $X$ rozkładem wykładniczym, funkcja gęstości zmiennej $T$ przyjmuje następującą postać: 


$$
\begin{array}{r}
f_{T}(x)=\frac{\lambda}{2} \exp \left(\lambda^{2}\left(\sigma_{Y}^{2}+\sigma_{W}^{2}+\sigma_{Z}^{2}\right)-\lambda x\right) . \\
\left(1+\operatorname{erf}\left(\frac{x-2 \lambda\left(\sigma_{Y}^{2}+\sigma_{W}^{2}+\sigma_{Z}^{2}\right)}{2 \sqrt{\sigma_{Y}^{2}+\sigma_{W}^{2}+\sigma_{Z}^{2}}}\right)\right)
\end{array}
$$

gdzie

$\sigma_{Y}$ - odchylenie standardowe zmiennej $Y$;

$\sigma_{W}$ - odchylenie standardowe zmiennej $W$.

$\sigma_{Z}$ - odchylenie standardowe zmiennej $Z$.

$\lambda$ - parametr rozkładu wykładniczego;

$\operatorname{erf}(x)$ - funkcja błędu używana w programie Mathematica [2].

\section{Podsumowanie}

Ograniczenia w ruchu statków na torze wodnym spowodowane przepisami torowymi sprawiają, że strumień ruchu statków przestaje być strumieniem Poissona. Wyodrębnienie poszczególnych faz ruchu statków dla rozpatrywanych ograniczeń i zastosowanie metody splotu rozkładów umożliwiło wyznaczenie ogólnej postaci funkcji gęstości czasu oczekiwania na zgłoszenie kolejnej jednostki w zaburzonym strumieniu ruchu statków. Aby wyznaczyć konkretne funkcje gęstości dla określonego akwenu niezbędne są badania, mające na celu wyznaczenie rozkładów prawdopodobieństwa najlepiej opisujących wszystkie zmienne występujące w poszczególnych fazach ruchu statków.

Dr KASYK Lech, adiunkt w Zakładzie Matematyki Akademii Morskiej w Szczecinie; zajmuje się ruchem statków na skrzyżowaniach dróg wodnych oraz wpływem zaburzeń na strumień ruchu statków. 